\title{
Effect of Nitrogen and Sulphur on the Performance of Blackgram (Vigna mungo L.) under Custard Apple (Annona squamosa L.) based Agri-Horti System
}

\author{
Sheelendra Kumar ${ }^{1}$, Makhan Singh Karada ${ }^{1}$, Jiwan Paudel ${ }^{2}$ and U. P. Singh ${ }^{1}$ \\ ${ }^{1}$ Department of agronomy, Institute of Agricultural Sciences, B.H.U. Varanasi-221005, India \\ ${ }^{2}$ Rajiv Gandhi South Campus, Banaras Hindu University, Barkachha, \\ Mirzapur 231001, UP, India \\ *Corresponding author
}

\section{A B S T R A C T}

\section{Keywords}

Nitrogen, Nodule, Stover, Vindhyan, Yield

\section{Article Info}

\section{Accepted:}

26 April 2020

Available Online:

10 May 2020
A field experiment was carried out during Kharif season of 2018 to evaluate Effect of nitrogen and sulphur on the performance of blackgram under custard apple (Annona squamosa L.) based agrihorti system. The result indicated that Number of nodules plant ${ }^{-1}$ decreased drastically from 30 to 50 DAS of crop. The maximum root nodules plant ${ }^{-1}$ was found at highest nitrogen $\left(40 \mathrm{~kg} \mathrm{~N} \mathrm{ha}^{-1}\right)$ and sulphur level $\left(40 \mathrm{~kg} \mathrm{~S}^{-1}\right)$ followed by, medium and over control at 30 and 50 DAS. The maximum dry matter accumulation plant ${ }^{-1}$ was observed at $40 \mathrm{~kg} \mathrm{~N}$ and $40 \mathrm{~kg} \mathrm{~S}^{-1}$ whereas; lowest dry matter accumulation was found under control. Increasing levels of $\mathrm{N}$ and $\mathrm{S}$ from control to $40 \mathrm{~kg} \mathrm{~N} \mathrm{ha}^{-1}$ and $40 \mathrm{~kg} \mathrm{~S} \mathrm{ha}^{-1}$ significantly increased the grain yield, stover yield, biological yield and harvest index of blackgram. The $\mathrm{N}$ and $\mathrm{S}$ contents in grain and stover of blackgram significantly improved due to 40 $\mathrm{kg} \mathrm{N} \mathrm{ha}^{-1}$ and $40 \mathrm{~kg} \mathrm{~S} \mathrm{ha}^{-1}$ whereas, minimum was found under control $(0 \mathrm{~kg} \mathrm{~N}$ and $0 \mathrm{~kg} \mathrm{~S}$ ha-1). The nutrient uptake in grain and stover of blackgram under custard apple based agri-horti system, increased markedly with increasing levels of nitrogen and sulphur and uptake highest with $40 \mathrm{~kg} \mathrm{~N}$ $\mathrm{ha}^{-1}$ and $40 \mathrm{~kg} \mathrm{~S} \mathrm{ha}^{-1}$ and lowest uptake was found under control. Protein content and protein yield were found statistically superior with $40 \mathrm{~kg} \mathrm{~N} \mathrm{ha}^{-1}$ and $40 \mathrm{~kg} \mathrm{~S}^{-1}$ while minimum was noted in control condition. The maximum gross returns (Rs 55,468 ha ${ }^{-1}$ ), net returns (Rs 26,472 ha $\mathrm{ha}^{-1}$ ) and benefit: cost ratio (1.94) were obtained with $40 \mathrm{~kg} \mathrm{~N} h a^{-1}$, although, maximum gross returns (Rs 54887 ha-1), net returns (Rs $24371 \mathrm{ha}^{-1}$ ) and benefit: cost ratio (1.83) was maintained by $40 \mathrm{~kg} \mathrm{~S}^{-1}$ and minimum net returns (Rs $17719 \mathrm{ha}^{-1}$ ) and benefit: cost ratio (1.38) in control condition.

\section{Introduction}

Black gram (Vigna mungo L.) is a widely grown legume that belongs to the fabaceae family and assumes considerable importance from the point of view of food and nutritional security in the world. It is a favorable shortterm pulse crop as it thrives better in all seasons either as a sole crop or as an intercrop or fallow crop. India is the world's largest producer and consumer of black gram. It produces about 1.5-1.9 million tons of black grams per year from about 3.5 million hectares of an area, with an average productivity of $600 \mathrm{~kg} \mathrm{ha}^{-1}$ and its output accounts for about 10 percent of India's total pulse output. Black gram is a perfect combination of all nutrients, including 
proteins (25-26 percent), carbohydrates (60 percent), fat (1.5 percent), minerals, amino acids and vitamins (Karamany, 2006).

Custard apple (Annona squamosa L.) belongs to the Annonaceae family, which includes more than 2000 species of mostly tropical trees and shrubs. The most frequently eaten species is simply referred to as the custard apple. It is native to tropical America and West Indies. Custard apple is grown in the tropics and subtropics of America, New Zealand, India, Brazil, Argentina, and Venezuela. In India it is mainly cultivated in states such as Andhra Pradesh, Maharashtra, Karnataka, Assam, Bihar, Orissa and Tamilnadu. Custard apple is a nutritive fruit due to the fact that its 100 gram edible portion contains 1.5 per cent of protein, 23.5 per cent carbohydrates, $17 \mathrm{mg}$ calcium, $47 \mathrm{mg}$ phosphorus, $1.5 \mathrm{mg}$ iron, 0.07 per cent thiamine, $0.17 \mathrm{mg}$ riboflavin, $1.3 \mathrm{mg}$ niacin and $37 \mathrm{mg}$ ascorbic acid (Shrivastava and Kumar, 1998).

Nitrogen is an essential plant nutrient involved in physiological processes and enzyme activity. The nitrogen requirement of pulses is very low than other crops because it requires nitrogen only for plant establishment, after which the plant fulfill its requirement through symbiotic nitrogen fixation. Normal metabolic activities can only continue in the presence of optimum nitrogen levels. Sulphur is considered to be the major plant nutrient after nitrogen, and its low availability in various soils causes an inherent sulphur deficiency. Sulphur plays a vital role in plant growth as well as legume metabolism. It is a part of nitrogenase enzymes, promoting leguminous nodulation. An adequate supply of sulphur can drastically reduce what enhances biological N-fixation (BNF) and pulse productivity. Sulphur plays very important role in Chlorophyll formation and also helps in biosynthesis of oil, carbohydrate, protein and fat metabolism (Das etal.2016). Sulphur influences the growth of plants in two ways, first by acting as a nutrient and secondly by improving the favorable soil condition.

\section{Materials and Methods}

The experiment was conducted at the Rajiv Gandhi South Campus Agricultural Research Farm, Barkachha (BHU) Mirzapur, located in the Vindhyan district of Mirzapur (25010" latitude, 82037" longitude and 427 meters above sea level), covering an area of more than 1000 ha-1. where a variety of crops such as agricultural, horticultural, medicinal and aromatic plants are grown. Vindhyan soil is rainfed and has an invariably poor fertility status. This region is covered by agro-climatic zone III A (semi-arid eastern plain zone) and the region is mostly rainfed. Experiment was laid out in a factorial randomized complete block design with three replication during rainy Kharif season of 2018 in eleven years aged Custard Apple tree which were planted in August 2008 at a spacing of $5 \times 5 \mathrm{~m} 2$. Blackgram was sown as intercrop in the alleys of custard apple tree. Each replication was divided into 12 equal plots and treatment was randomly allocated within the block for each replication. The treatment comprising of T1$0 \mathrm{Kg} / \mathrm{ha}$ Nitrogen $+0 \mathrm{Kg} / \mathrm{ha}$ Sulphur (N1S0), T2- $0 \mathrm{Kg} / \mathrm{ha}$ Nitrogen $+20 \mathrm{Kg} / \mathrm{ha}$ Sulphur (N1S1), T3-0 Kg/ha Nitrogen + $30 \mathrm{Kg} / \mathrm{ha}$ Sulphur (N1S2), T4- $0 \mathrm{Kg} / \mathrm{ha}$ Nitrogen +40 $\mathrm{Kg} / \mathrm{ha}$ Sulphur (N1S3), T5- $20 \mathrm{Kg} / \mathrm{ha}$ Nitrogen + $0 \mathrm{Kg} /$ ha Sulphur (N2S0), T6- 20 $\mathrm{Kg} / \mathrm{ha}$ Nitrogen $+20 \mathrm{Kg} / \mathrm{ha}$ Sulphur (N2S1), T7- $20 \mathrm{Kg} / \mathrm{ha}$ Nitrogen $+30 \mathrm{Kg} / \mathrm{ha}$ Sulphur (N2S2), T8- $20 \mathrm{Kg} / \mathrm{ha}$ Nitrogen + $40 \mathrm{Kg} / \mathrm{ha}$ Sulphur (N2S3), T9- $40 \mathrm{Kg} / \mathrm{ha}$ Nitrogen +0 $\mathrm{Kg} / \mathrm{ha}$ Sulphur (N3S0), T10- $40 \mathrm{Kg} / \mathrm{ha}$ Nitrogen + $20 \mathrm{Kg} / \mathrm{ha}$ Sulphur (N3S1), T11$40 \mathrm{Kg} / \mathrm{ha}$ Nitrogen $+30 \mathrm{Kg} / \mathrm{ha}$ Sulphur (N3S2), T12- $40 \mathrm{Kg} / \mathrm{ha}$ Nitrogen $+40 \mathrm{Kg} / \mathrm{ha}$ Sulphur (N3S3). The desired amount of 
nitrogen and sulphur were applied just before sowing in furrow opened by spade below near about $5 \mathrm{~cm}$ deep. The seeds of variety "URD KUG-479" were sown on 11/08/2018 manually in the rows operated by kudal at a row distance of $30 \mathrm{~cm}$ apart; harvesting was done on $10 / 11 / 2018$.

\section{Soil characteristics}

The physical properties of soil includes course sand (\%) 10.35, fine sand (\%) 48.32, silt $(\%) 19.42$, clay (\%)21.97, textural class sandy clay loam (Typic Ustochrepts), bulk density $\left(\mathrm{Mgm}^{-3}\right)$ 1.26, particle density 2.47 $\mathrm{Mgm}^{-3}$. Similarly chemical properties includes $\mathrm{pH}$ (1:2.5, soil and water ratio) 5.9, Electrical conductivity(1:2Soil: Water suspension) $\left(\mathrm{dSm}^{-1}\right.$ at $\left.25^{\circ} \mathrm{C}\right) \quad 0.31$, Organic carbon (\%) 0.49, Available nitrogen 153.32 $\mathrm{kg} \mathrm{ha}^{-1}$, Available phosphorus $\left(\mathrm{kg} \mathrm{ha}^{-1}\right)$ 14.15, Available potassium 217.58 (kg ha $\left.{ }^{-1}\right)$, Available sulphur $12.14 \mathrm{~kg} \mathrm{ha}^{-1}$.

\section{Chemical analysis of plant sample}

For estimation of nitrogen and sulphur representative samples of seed and stover were taken at the time of threshing. Each dried stover sample was grind in fine powder in Willey mill for estimation of nutrient content. Protein content in seed was calculated by multiplying the nitrogen percentage with 6.25 . The $0.5 \mathrm{~g}$ oven dried plant sample digested and nitrogen was estimated by the micro-Kjeldahl method Jackson (1973). The percentage nitrogen was multiplied with seed and stover yield into obtained Nitrogen uptake in $\mathrm{kg} \mathrm{ha}^{-}{ }^{1}$. The sulphur content in the digested plant samples was determined by turbidity methods acid yellow colour, using spectrophotometer at $340 \mathrm{~nm}$ wave length Chesnin and Yien (1950). The percentage sulphur was multiplied with seed and stover yield to obtained sulphur uptake in $\mathrm{kg} \mathrm{ha}^{-1}$.

\section{Results and Discussion}

Maximum plant height was observed with 40 $\mathrm{kg} \mathrm{N} \mathrm{ha}{ }^{-1}$ which was found significantly superior over $20 \mathrm{~kg} \mathrm{~N} \mathrm{ha}^{-1}$ and control at 40 , 60 DAS and at harvest (Fig. 1).

Among the different level of sulphur, plant height was recorded highest in $40 \mathrm{~kg} \mathrm{~S}^{-1}$ and found significantly superior than $0 \mathrm{~kg} \mathrm{~S}$ $\mathrm{ha}^{-1}$ and $20 \mathrm{~kg} \mathrm{~S} \mathrm{ha}^{-1}$ but it was found to be at par with $30 \mathrm{~kg} \mathrm{~S} \mathrm{ha}^{-1}$ at 40, 60 DAS and at harvest (Fig. 2).

With the increase in nitrogen dose, the number of nodules plant $^{-1}$ increased correspondingly over rest of nitrogen levels at 30 DAS. Whereas, at 50 DAS, $40 \mathrm{~kg} \mathrm{~N}^{-1}$ was found statistically at par with $20 \mathrm{~kg} \mathrm{~N}^{-}$ 1 and significantly superior over control (Fig. 3). All the sulphur levels showed marked differences in number of nodules plant ${ }^{-1}$. At 30 DAS, Highest sulphur level was differing significantly over rest of sulphur doses and over control. The highest dry matter accumulation plant ${ }^{-1}$ was found at $40 \mathrm{~kg} \mathrm{~N} \mathrm{ha}^{-1}$ (Fig. 4).

And it was statistically superior over $20 \mathrm{~kg}$ $\mathrm{Nha}^{-1}$ and control whereas, $40 \mathrm{~kg} \mathrm{~S} \mathrm{ha}{ }^{-1}$ maintained maximum dry matter accumulation at harvest over rest of the sulphur doses and over control (Fig. 5). Highest test weight (32.29) was found with 40 $\mathrm{kg} \mathrm{N} \mathrm{ha}{ }^{-1}$. However differences among the different nitrogen levels, test was couldn't touch the levels of significance. As regards the four levels of sulphur, $40 \mathrm{~kg} \mathrm{~S} \mathrm{ha}{ }^{-1}$ recorded higher test weight (32.41). Increasing levels of nitrogen from $0 \mathrm{~kg} \mathrm{~N} \mathrm{ha}^{-1}$ to $40 \mathrm{~kg} \mathrm{~N} \mathrm{ha}^{-1}$ markedly increased the grain yield. However, the differences among the nitrogen levels, $40 \mathrm{~kg} \mathrm{~N} \mathrm{ha}{ }^{-1}$ recorded significantly higher grain yield $\left(777 \mathrm{~kg} \mathrm{ha}^{-1}\right)$ which was found 6.69 per cent and 17.24 per cent more over $20 \mathrm{~kg} \mathrm{~N} \mathrm{ha}^{-1}$ and over control (Table 1). 
Table.1 Effect nitrogen and sulphur on grain yield, stover yield, biological yield and harvest index of blackgram under custard apple based agri-horti system

\begin{tabular}{|c|c|c|c|c|}
\hline \multirow[t]{2}{*}{ Treatment } & \multicolumn{4}{|c|}{ Yield } \\
\hline & $\begin{array}{l}\text { Grain yield } \\
\left(\mathrm{kgha}^{-1}\right)\end{array}$ & $\begin{array}{l}\text { Stover yield } \\
\left(\mathrm{kg} \mathrm{ha}^{-1}\right)\end{array}$ & $\begin{array}{l}\text { Biological yield } \\
\qquad\left(\mathrm{kg} \mathrm{ha}^{-1}\right)\end{array}$ & $\begin{array}{c}\text { Harvest } \\
\text { Index }(\%)\end{array}$ \\
\hline \multicolumn{5}{|c|}{ Nitrogen level $\left(\mathrm{kg} \mathrm{ha}^{-1}\right)$} \\
\hline $\mathrm{N}_{1-}-0 \mathrm{~kg}$ & 643 & 1669 & 2312 & 27.80 \\
\hline $\mathrm{N}_{2}-20 \mathrm{~kg}$ & 725 & 1837 & 2562 & 28.24 \\
\hline $\mathrm{N}_{3}-40 \mathrm{~kg}$ & 777 & 1963 & 2741 & 28.33 \\
\hline SEm \pm & 12 & 28 & 39 & 0.24 \\
\hline $\mathrm{CD}(\mathrm{P}=0.05)$ & 37 & 84 & 115 & 0.71 \\
\hline \multicolumn{5}{|l|}{ Sulphur level $\left(\mathrm{kg} \mathrm{ha}^{-1}\right)$} \\
\hline$S_{0^{-}} \quad 0 k g$ & 640 & 1691 & 2332 & 27.51 \\
\hline$S_{1-20 k g}$ & 706 & 1807 & 2514 & 28.07 \\
\hline $\mathrm{S}_{2^{-}} \mathbf{3 0 \mathrm { kg }}$ & 744 & 1845 & 2590 & 28.61 \\
\hline $\mathrm{S}_{3}-40 \mathrm{~kg}$ & 769 & 1949 & 2718 & 28.30 \\
\hline SEm \pm & 14 & 33 & 45 & 0.28 \\
\hline $\mathrm{CD}(\mathrm{P}=\mathbf{0 . 0 5})$ & 43 & 97 & 132 & 0.82 \\
\hline
\end{tabular}

Table.2 Effect of nitrogen and sulphur on Nitrogen and sulphur content of blackgram under custard apple based agri-horti system

\begin{tabular}{|c|c|c|c|c|}
\hline \multirow[t]{3}{*}{ Treatment } & \multicolumn{3}{|c|}{ Content (\%) } & \\
\hline & \multicolumn{2}{|c|}{ Grain } & \multicolumn{2}{|l|}{ Stover } \\
\hline & $\mathrm{N}$ & $S$ & $\mathrm{~N}$ & $S$ \\
\hline \multicolumn{5}{|c|}{ Nitrogen level $\left(\mathrm{kg} \mathrm{ha}^{-1}\right)$} \\
\hline $\mathrm{N}_{1}-0 \mathrm{~kg}$ & 3.69 & 0.67 & 1.15 & 0.35 \\
\hline $\mathrm{N}_{2}-20 \mathrm{~kg}$ & 3.86 & 0.68 & 1.32 & 0.51 \\
\hline $\mathrm{N}_{3^{-}}-40 \mathrm{~kg}$ & 4.12 & 0.92 & 1.55 & 0.66 \\
\hline SEm \pm & 0.04 & 0.05 & 0.02 & 0.03 \\
\hline $\mathrm{CD}(\mathrm{P}=0.05)$ & 0.12 & 0.15 & 0.07 & 0.09 \\
\hline \multicolumn{5}{|c|}{ Sulphur level $\left(\mathrm{kg} \mathrm{ha}^{-1}\right)$} \\
\hline$S_{0^{-}} \quad 0 \mathrm{~kg}$ & 3.58 & 0.39 & 1.15 & 0.20 \\
\hline $\mathrm{S}_{1-} \mathbf{2 0 \mathrm { kg }}$ & 3.68 & 0.50 & 1.23 & 0.37 \\
\hline$S_{2-} \mathbf{3 0 k g}$ & 3.96 & 0.81 & 1.42 & 0.58 \\
\hline $\mathrm{S}_{3}-40 \mathrm{~kg}$ & 4.34 & 1.34 & 1.55 & 0.88 \\
\hline SEm \pm & 0.05 & 0.06 & 0.03 & 0.04 \\
\hline
\end{tabular}


Table.3 Economics of blackgram as influenced by $\mathrm{N}$ and $\mathrm{S}$ levels under custard apple based agri-horti system

\begin{tabular}{|c|c|c|c|c|}
\hline Treatment & $\begin{array}{c}\text { Cost of } \\
\text { cultivation }\left(h^{-1}\right)\end{array}$ & $\begin{array}{c}\text { Gross return } \\
\left(\text { ha }^{-1}\right)\end{array}$ & $\begin{array}{l}\text { Net return } \\
\left(\text { ha }^{-1}\right)\end{array}$ & B:C ratio \\
\hline \multicolumn{5}{|c|}{ Nitrogen level $\left(\mathrm{kg} \mathrm{ha}^{-1}\right)$} \\
\hline$N_{1}-\quad 0 k g$ & 28249 & 45968 & 17719 & 1.62 \\
\hline $\mathrm{N}_{2}-20 \mathrm{~kg}$ & 28715 & 51724 & 23010 & 1.80 \\
\hline $\mathrm{N}_{3}-40 \mathrm{~kg}$ & 28996 & 55468 & 26472 & 1.94 \\
\hline SEm \pm & & 886 & 886 & 0.03 \\
\hline $\mathrm{CD}(\mathbf{P}=0.05)$ & & 2598 & 2598 & 0.09 \\
\hline \multicolumn{5}{|c|}{ Sulphur level $\left(\mathrm{kg} \mathrm{ha}^{-1}\right)$} \\
\hline$S_{0^{-}} \quad 0 \mathrm{~kg}$ & 26233 & 45858 & 19625 & 1.75 \\
\hline $\mathrm{S}_{1-} \quad 20 \mathrm{~kg}$ & 28414 & 50459 & 22045 & 1.77 \\
\hline$S_{2}-30 \mathrm{~kg}$ & 29451 & 53010 & 23560 & 1.80 \\
\hline$S_{3}-40 \mathrm{~kg}$ & 30515 & 54887 & 24371 & 1.83 \\
\hline SEm \pm & & 1023 & 1023 & 0.01 \\
\hline $\mathrm{CD}(\mathrm{P}=0.05)$ & & 3000 & 3000 & 0.03 \\
\hline
\end{tabular}

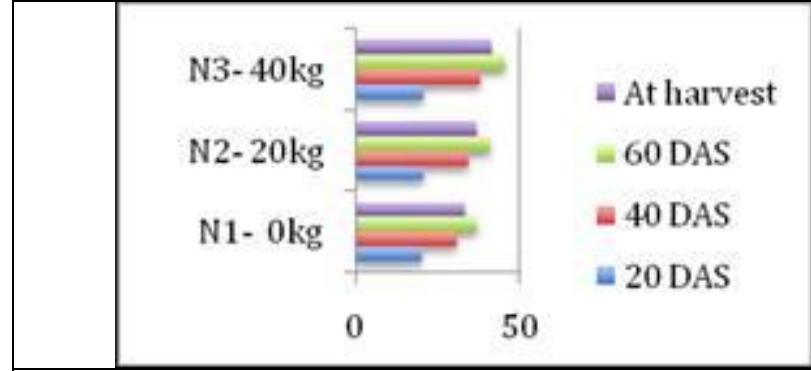

Fig.1 Effect of nitrogen on plant height $(\mathrm{cm})$ of blackgram under custard apple based agri-horti system

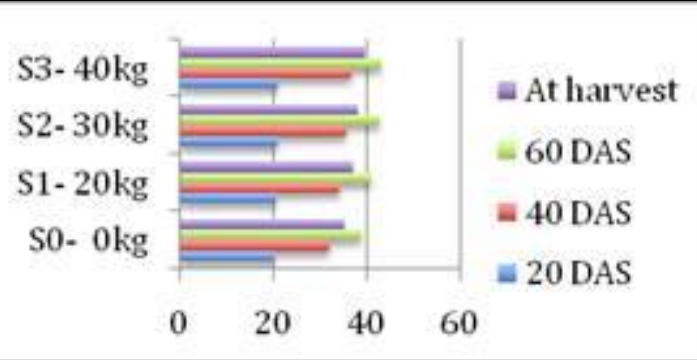

Fig.2 Effect of sulphur on plant height $(\mathrm{cm})$ of blackgram under custard apple based agri-horti system

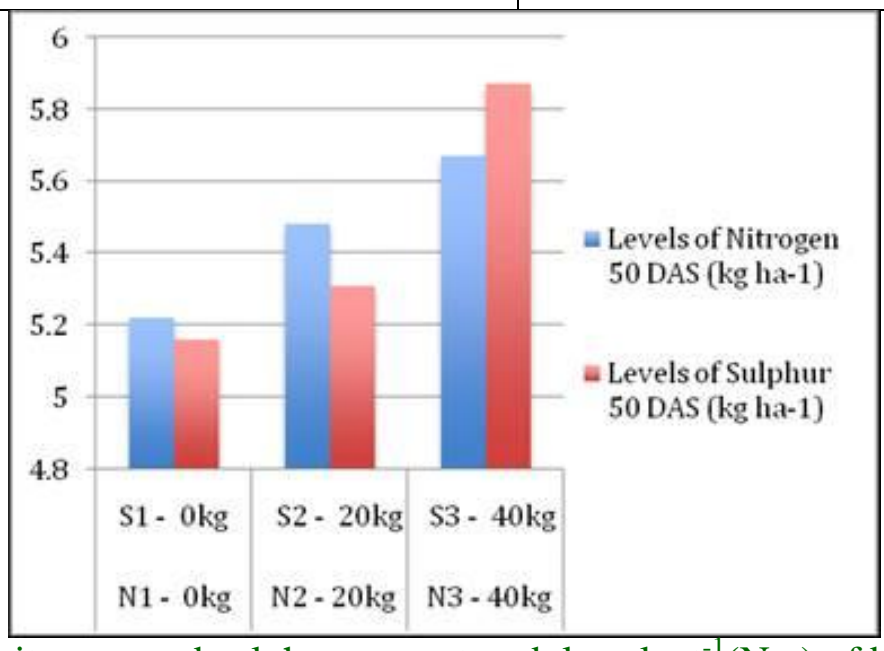

Fig.3 Effect of nitrogen and sulphur on root nodules plant ${ }^{-1}$ (No.) of blackgram under custard apple based agri-horti system 


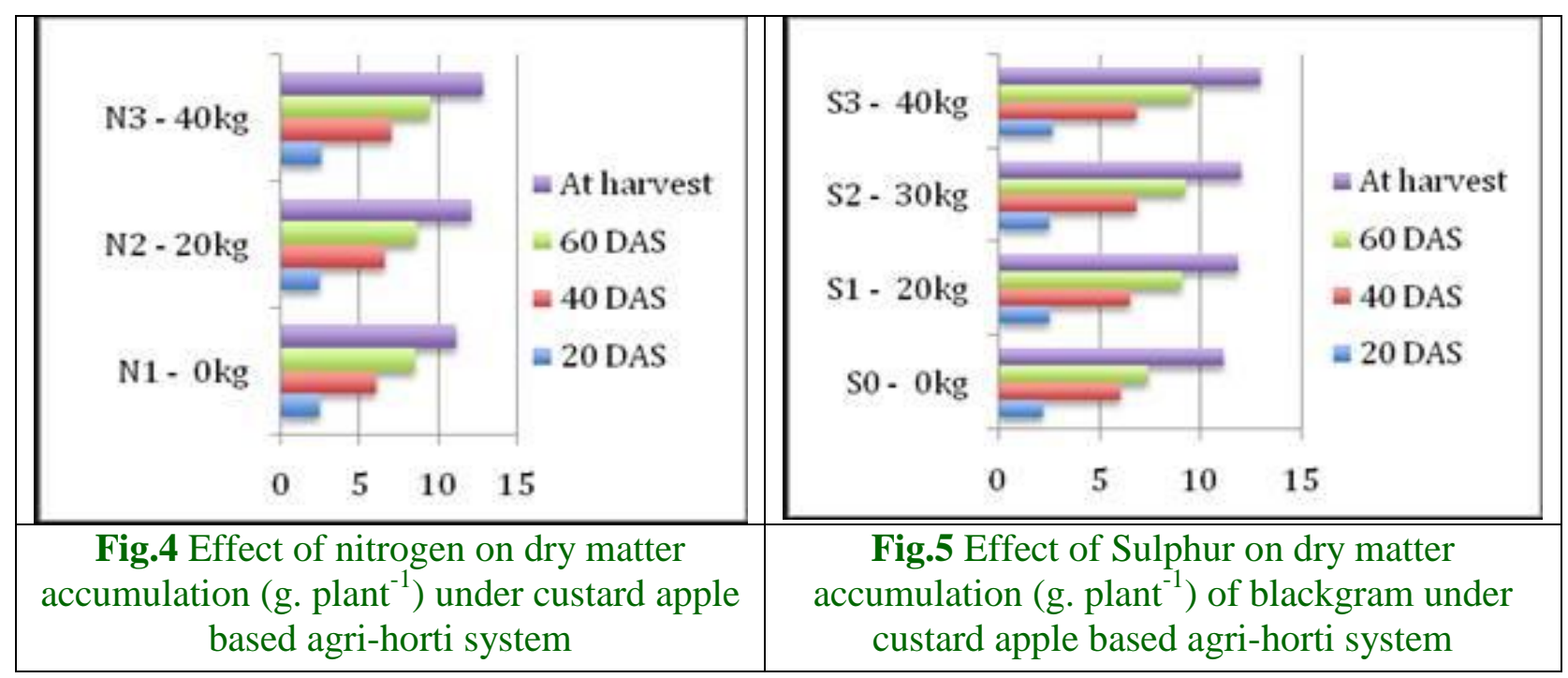

Highest dose (40 $\mathrm{kg} \mathrm{S} \mathrm{ha}{ }^{-1}$ ) of sulphur produced significantly highest nitrogen content in stover of black gram, than by $30 \mathrm{~kg}$ $\mathrm{S} \mathrm{ha}^{-1}, 20 \mathrm{~kg} \mathrm{~S} \mathrm{ha}^{-1}$ and over control. Increasing levels of nitrogen application from $0 \mathrm{~kg} \mathrm{~N} \mathrm{ha}{ }^{-1}$ to $40 \mathrm{~kg} \mathrm{ha}^{-1}$, significantly increased the sulphur content in stover. Highest sulphur level (40 kg S ha ${ }^{-1}$ ) was maintained higher sulphur content $(0.88$ per cent) over $30 \mathrm{~kg} \mathrm{~S} \mathrm{ha}^{-1}, 20 \mathrm{~kg} \mathrm{~S} \mathrm{ha}{ }^{-1}$ and control (Table 2).

Due to different nitrogen levels protein content was found maximum (25.77) in $40 \mathrm{~kg}$ $\mathrm{N} \mathrm{ha}^{-1}$ and showed distinctive significant characters over control. Highest levels of sulphur (40 $\mathrm{kg} \mathrm{S} \mathrm{ha}^{-1}$ ) produced significantly higher protein content and protein yield over $30,20 \mathrm{~kg} \mathrm{~S} \mathrm{ha}^{-1}$ and over control.

\section{Economics}

Highest nitrogen level $40 \mathrm{~kg} \mathrm{ha}^{-1}$ significantly recorded highest gross return (Rs. 55,468 ha ${ }^{1}$ ) followed by $20 \mathrm{~kg} \mathrm{~N}^{-1}$ (Rs. 51,724 ha ${ }^{-1}$ ) and over control (Rs. 45,968 ha ${ }^{-1}$ ). Data regarding different sulphur levels, highest sulphur level (40 $\mathrm{kg} \mathrm{S} \mathrm{ha}^{-1}$ ) produced maximum gross return (Rs. 54,887 $\mathrm{ha}^{-1}$ ) and found significantly superior over the rest of the treatments. increasing levels of nitrogen from lowest to highest, maintained significantly increased net returns (Rs. 26,472 $\mathrm{ha}^{-1}$ ) over the rest of the treatments (Table 3 ).

Highest net returns (Rs. 24,371 ha ${ }^{-1}$ ) was noticed due to highest sulphur level $(40 \mathrm{~kg} \mathrm{~S}$ $\mathrm{ha}^{-1}$ ) and found significantly superior over 30 , $20 \mathrm{~kg} \mathrm{~S} \mathrm{ha}{ }^{-1}$ and control. Highest level of nitrogen (40 $\mathrm{kg} \mathrm{S} \mathrm{ha}^{-1}$ ) produced maximum benefit cost ratio (1.94) over the $20 \mathrm{~kg} \mathrm{~N}^{-1}$ and control and highest sulphur level (40 kg S $\mathrm{ha}^{-1}$ ) produced highest benefit cost ratio (1.83).

Based on the experimental results and economics, it could be recommended that growing of blackgram along with nitrogen 40 $\mathrm{kg} \mathrm{ha}^{-1}$ and sulphur $40 \mathrm{~kg} \mathrm{ha}^{-1}$ intercropped in alley of custard apple may be beneficial for boosting grain yield, higher net return, maximum benefit cost ratio and better profitability in the Vindhyan region of Mirzapur.

\section{References}

Chesnin L, Yien CH (1950) Turbidimetric determination of available sulphates. Soil SciSoc Am Proc 15: 149- 151

Das SK, Biswas B, Jana K. Effect of farm 
yard manure, phosphorus and sulphur on yield parameters, yield, nodulation, nutrient uptake and quality of chickpea (Cicer arietinum L.). J Appl. \& Nat. Sci. 2016; 8(2):545- 549.

Jackson, M.L. (1973) Soil Chemical Analysis. Prentice Hall of India Pvt. Ltd. New Delhi.

Karamany EL (2006). Double purpose (forage and seed) of mung bean production 1- effect of plant density and forage cutting date on forage and seed yields of mung bean (Vigna radiata (L.) Wilczck). Res. J. Agric. Biol. Sci. 2: 162-165.

Shrivastava, R.P. and Kumar, S. 1998. Fruits and vegetable preservation principles and practices. International Book Distributing Company, Lucknow.

\section{How to cite this article:}

Sheelendra Kumar, Makhan Singh Karada, Jiwan Paudel and Singh, U. P. 2020. Effect of Nitrogen and Sulphur on the Performance of Blackgram (Vigna mungo L.) under Custard Apple (Annona squamosa L.) based Agri-Horti System. Int.J.Curr.Microbiol.App.Sci. 9(05): 3339-3345. doi: https://doi.org/10.20546/ijcmas.2020.905.397 